Growth Differenti at i on Fact or 9 I s Ant i apopt ot i c dur i ng Fol I i cul ar Devel opment from Preantral to Early Antral Stage

\begin{tabular}{|l|l|}
\hline 著者 & $\begin{array}{l}\text { ORI SAKA Nakot o, ORI SAKA Sanae, Ji ang Ji n- Yi , } \\
\text { Cr ai g J esse, WANG Yi f ang, KOTSUJ I Fumi kazu, } \\
\text { Tsang Benj ami n K }\end{array}$ \\
\hline $\begin{array}{l}\text { j our nal or } \\
\text { publ i cat i on ti tl e }\end{array}$ & Mbl ecul ar Endocr i nol ogy \\
\hline vol une & 20 \\
\hline number & 10 \\
\hline page r ange & 2456 \\
\hline year & $2006-05$ \\
\hline URL & ht t p: //hdl . handl e. net $/ 10098 / 1505$ \\
\hline
\end{tabular}




\title{
Growth Differentiation Factor 9 Is Antiapoptotic during Follicular Development from Preantral to Early Antral Stage
}

\author{
Makoto Orisaka, Sanae Orisaka, Jin-Yi Jiang, Jesse Craig, Yifang Wang, Fumikazu Kotsuji, and \\ Benjamin K. Tsang \\ Reproductive Biology Unit and Division of Reproductive Medicine (M.O., S.O., J.-Y.J., J.C., Y.W., \\ B.K.T.), Department of Obstetrics and Gynaecology and Cellular and Molecular Medicine, University \\ of Ottawa, Ottawa Health Research Institute, The Ottawa Hospital (Civic Campus), Ottawa, Ontario, \\ Canada K1Y 4E9; and Department of Obstetrics and Gynecology (M.O., S.O., F.K.), University of \\ Fukui, Matsuoka, Fukui, Japan 910-1193
}

Ovarian follicular atresia represents a selection process that ensures the release of only healthy and viable oocytes during ovulation. The transition from preantral to early antral stage is the penultimate stage of development in terms of gonadotropin dependence and follicle destiny (survival/ growth vs. atresia). We have examined whether and how oocyte-derived growth differentiation factor 9 (GDF-9) and FSH regulate follicular development and atresia during the preantral to early antral transition, by a novel combination of in vitro gene manipulation (i.e. intraoocyte injection of GDF-9 antisense oligos) and preantral follicle culture. Injection of GDF-9 antisense suppressed basal and FSH-induced preantral follicle growth in vitro, whereas addition of GDF-9 enhanced basal and FSH-induced follicular development. GDF-9 antisense activated caspase- 3 and induced apoptosis in cultured preantral follicles, a response attenuated by exogenous GDF-9. GDF-9 increased
phospho-Akt content in granulosa cells of early antral follicles. Although granulosa cell apoptosis induced by ceramide was attenuated by the presence of GDF -9 , this protective effect of GDF -9 was prevented by the phosphatidylinositol 3-kinase inhibitor LY294002 and a dominant negative form of Akt. Injection of GDF-9 antisense decreased FSH receptor mRNA levels in cultured follicles, a response preventable by the presence of exogenous GDF-9. The data suggest that GDF-9 is antiapoptotic in preantral follicles and protects granulosa cells from undergoing apoptosis via activation of the phosphatidylinositol 3-kinase/Akt pathway. An adequate level of GDF-9 is required for follicular FSH receptor mRNA expression. GDF-9 promotes follicular survival and growth during the preantral to early antral transition by suppressing granulosa cell apoptosis and follicular atresia.

growth of these follicles is controlled primarily by intraovarian mechanisms and, although unaffected by the absence of gonadotropins $(2,3)$, is stimulated by the presence of FSH $(1,4,5)$, and 3) continual growth beyond the early antral stage (gonadotropin-dependent phase), which includes follicle recruitment, selection, and ovulation (6). In mammals, a single or small number of germ cell(s) will ovulate during an ovarian cycle, whereas most follicles undergo atresia by follicle cell apoptosis $(1,7)$, a selection process that ensures the release of only the healthiest and most viable oocytes $(8,9)$.

Follicles selected for further development are thought to receive precise signals from gonadotropins and locally produced growth factors for survival, whereas follicular atresia is a consequence of inadequate growth support (10). Although apoptosis can occur at all stages of follicular development, the early antral follicles (diameter: $200-400 \mu \mathrm{m}$ in rats; $2-5 \mathrm{~mm}$ in human) are most susceptible to atretogenic signals $(1,11)$. In contrast, minimal atresia or granulosa cell apoptosis is evident in preantral and the smallest an- 
tral follicles (diameter: $<200 \mu \mathrm{m}$ in rats; $<2 \mathrm{~mm}$ in humans) $(7,12)$. Accordingly, the preantral to early antral transition is the penultimate stage of development in terms of gonadotropin dependence and follicle destiny (survival/growth vs. atresia). Although oocyte-somatic cell communication is believed to play a critical role in folliculogenesis, including activation of resting follicles, early growth, and terminal differentiation (13-17), whether oocytes play a role in the determining fate of the follicle, by regulating follicle cell apoptosis during the preantral to early antral transition, is not known. It is also not clear whether and by what means oocyte-derived factor(s) may influence the integrity of the granulosa layer via paracrine actions to promote follicular cell survival and growth during this stage of development.

Growth differentiation factor-9 (GDF-9) is an oocytederived factor and a member of the TGF- $\beta$ superfamily, which includes TGF- $\beta$, activin, and bone morphogenetic proteins (BMPs) $(18,19)$. GDF-9 is expressed in the mammalian oocyte throughout follicular development (20-23). Deletion of the GDF-9 gene in mice blocked folliculogenesis at the primary stage, demonstrating the importance of this growth factor in early follicular development (21). Subsequent studies have shown that GDF-9 stimulates granulosa cell proliferation (24), preantral follicle growth (22), and cumulus cell expansion (25), whereas it suppresses FSH-induced CAMP production and steroidogenesis (24). Treatment with GDF-9 resulted in a higher proportion of viable human follicles in organ culture, suggesting a possible role of GDF-9 in follicular survival (26). Although GDF-9 promotes granulosa cell mitosis and preantral follicle growth, whether this latter response is mediated via suppressed apoptosis is not known.

In the present studies, we hypothesized that oocytederived GDF-9 is an antiapoptotic factor and promotes preantral follicular growth, in part, by suppressing granulosa cell apoptosis. We have examined whether and by what means GDF-9 and FSH regulate follicular development and atresia during the preantral to early antral transition, by a novel combination of in vitro gene manipulation and preantral follicle culture. We have demonstrated that GDF-9 is antiapoptotic in cultured preantral follicles and protects granulosa cells from undergoing apoptosis via activation of the phosphatidylinositol 3-kinase (PI3K)/Akt pathway. In addition, an adequate level of GDF-9 is required for FSH receptor (FSHR) mRNA expression in follicles during this early stage of the development.

\section{RESULTS}

\section{GDF-9 and FSH Stimulate Preantral Follicle Growth in Vitro}

To examine the effect of GDF-9 and FSH on preantral follicle growth, large preantral follicles $(150-180 \mu \mathrm{m}$ in diameter) isolated from $14-d$-old rats were cultured with or without $100 \mathrm{ng} / \mathrm{ml}$ of GDF-9 and different concentrations of FSH ( 10 or $100 \mathrm{ng} / \mathrm{ml}$ ) for $4 \mathrm{~d}$. Preantral follicles cultured in the absence of GDF-9 and FSH exhibited minimal growth (follicular volume change at d $4: 30.7 \pm 2.0 \%$; Fig. 1). Addition of GDF-9 to the culture media significantly increased the follicular growth and the increase at $d 4$ was $105.7 \pm 7.1 \%(P<$ 0.01 vs. CTL; Fig. 1). FSH also stimulated preantral follicle growth, although it appeared more effective at $10 \mathrm{ng} / \mathrm{ml}(115.7 \pm 6.9 \%)$ than $100 \mathrm{ng} / \mathrm{ml}(89.1 \pm 4.6 \%)$ $(P=0.09)$. Moreover, GDF-9 significantly enhanced follicular growth induced by $10 \mathrm{ng} / \mathrm{ml}(164.6 \pm 15.7 \%$; $P<0.05)$ but not $100 \mathrm{ng} / \mathrm{ml}(101.7 \pm 11.2 \% ; P>0.05)$ of the gonadotropin (Fig. 1).

\section{Effect of GDF-9 and FSH on Follicle Cell Apoptosis in Cultured Follicles}

Preantral follicles cultured in the absence of GDF-9 and $\mathrm{FSH}$ did not reach $200 \mu \mathrm{m}$ in diameter, remained at the preantral stage on $\mathrm{d} 4$ (Fig. 2A), and exhibited minimal apoptosis as determined by terminal deoxynucleotidyltransferase-mediated dUTP nick end labeling (TUNEL) (Fig. 2B). Significant apoptosis was noted in follicles that grew to more than $200 \mu \mathrm{m}$ in diameter (corresponding to early antral stage) in the presence of $10 \mathrm{ng} / \mathrm{ml}$ of FSH (Fig. 2, C and D). Apoptosis was absent in follicles treated with $100 \mathrm{ng} / \mathrm{ml}$ FSH (Fig. 2, E and F) or GDF-9 (Fig. 2, G and H) even in early antral stage. The granulosa cells of $100 \mathrm{ng} / \mathrm{ml}$ FSH-treated follicles appeared to be detached from each other when observed under bright-field imaging

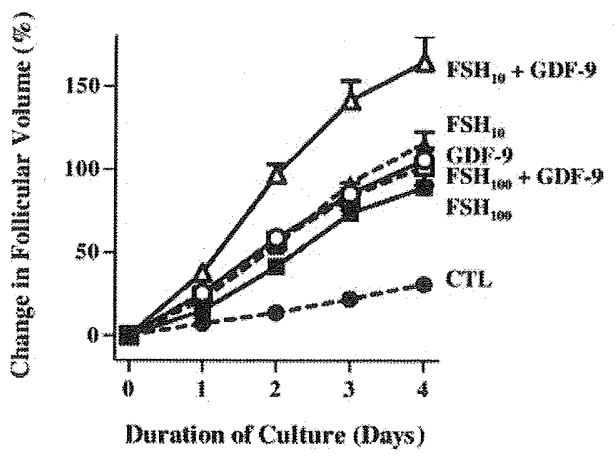

Fig. 1. Effects of GDF-9 and FSH on Preantral Follicle Growth in Vitro

Rat preantral follicles (150-180 $\mu \mathrm{m}$ in diameter) were cultured for $4 \mathrm{~d}$ with or without GDF-9 $(100 \mathrm{ng} / \mathrm{ml})$ and different concentrations of FSH $\left[10 \mathrm{ng} / \mathrm{ml}\left(\mathrm{FSH}_{10}\right)\right.$ or $100 \mathrm{ng} / \mathrm{ml}$ $\left(\mathrm{FSH}_{100}\right)$ ]. CTL, Preantral follicles cultured in the absence of GDF-9 and FSH. Follicular diameter was measured daily, and results were expressed as change in follicular volume. The percentage change of follicular volume on $d$ " $n$ " of culture is defined as the volume difference between $d$ " $n$ " and $d 0$ (the day of isolation) expressed as a percentage of the volume at d 0 . Results are represented as means \pm SEM of a total of 40 follicles from eight to 10 independent experiments. Note that GDF-9 stimulated basal and FSH (10 $\mathrm{ng} / \mathrm{ml})$-induced follicular growth. 

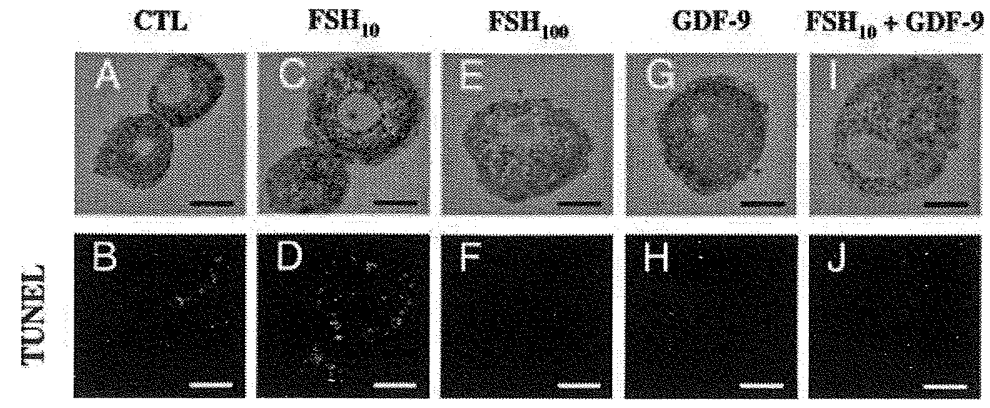

Fig. 2. Effects of GDF-9 and FSH on Follicle Cell Apoptosis in Vitro

Preantral follicles (150-180 $\mu \mathrm{m}$ in diameter) were cultured in the absence $(A$ and $B)$ and presence $(G$ and $H)$ of GDF-9 (100 $\mathrm{ng} / \mathrm{ml})$ and different concentrations of $\mathrm{FSH}\left[10 \mathrm{ng} / \mathrm{ml}\left(\mathrm{FSH}_{10}\right.\right.$; panels $\mathrm{C}$ and $\left.\mathrm{D}\right)$ or $100 \mathrm{ng} / \mathrm{ml}\left(\mathrm{FSH}_{100}\right.$; panels $\mathrm{E}$ and F)]. CTL, Preantral follicles cultured in the absence of GDF- 9 and FSH. Cell death in the follicles on $\mathrm{d} 4$ of culture was assessed by TUNEL. An image from 10 representative follicles is shown for each treatment group. Note that, although follicle cell apoptosis was noted in follicles which grew to more than $200 \mu \mathrm{m}$ in diameter in the presence of $10 \mathrm{ng} / \mathrm{ml}$ of FSH (D), this apoptotic response was markedly decreased with GDF-9 cotreatment $(J)$. Scale bar, $100 \mu \mathrm{m}$.

(Fig. 2E). Although apoptosis was noted in follicles cultured in the presence of $10 \mathrm{ng} / \mathrm{ml}$ of $\mathrm{FSH}$, this response was markedly decreased with GDF-9 cotreatment (Fig. 2, I and J).

\section{Intraoocyte Injection of GDF-9 Morpholino Induces Follicle Cell Apoptosis and Caspase-3 Activation in Cultured Follicles}

To assess the role of GDF-9 on follicular development and atresia during the preantral to early antral transition, GDF-9 Morpholino antisense oligos (GDF-9 MO, $10 \mu \mathrm{M}$ ) or its control Morpholino (CTL MO, $10 \mu \mathrm{M}$ ) was injected into the oocyte of cultured preantral follicles. Figure 3, panels $\mathrm{Aa}$ and $\mathrm{Ab}$, show GDF-9 positive staining and negative control (preincubated with blocking peptide), respectively. Injection of GDF-9 $\mathrm{MO}$, but not CTL MO, markedly decreased oocyte GDF-9 content (Fig. 3, panels $\mathrm{Ba}, \mathrm{Bc}$, and $\mathrm{C} ; P<0.01$ ) and induced follicle cell apoptosis at $d 4$ (Fig. 3, panel $\mathrm{B}, \mathrm{a}-\mathrm{d}$ ) and at $\mathrm{d} 6$ (Fig. 3, panel $\mathrm{B}, \mathrm{e}-\mathrm{h}$ ) in vitro.

To further examine the apoptotic response by GDF-9 down-regulation, caspase- 3 activity in CTL MO- and the GDF-9 MO-injected follicles was assayed, using a specific bioluminescent substrate of caspase-3. The GDF-9 $\mathrm{MO}$-injected follicles exhibited significant decreased bioluminescence on d 4 (78.0 $\pm 4.8 \% ; P<0.05)$, when compared with the CTL MO-injected follicles, indicating that GDF-9 down-regulation in cultured follicles increased caspase-3 activity (Fig. 3D). Although this increased caspase- 3 activity appears small, this is significant considering that granulosa cell apoptosis is heterogeneous in the follicle and a continuous process, and represents an early stage of follicular atresia.

\section{Intraoocyte Injection of GDF-9 Morpholino Suppresses Preantral Follicle Growth in Vitro}

Intraoocyte injection of GDF-9 MO suppressed basal and $\mathrm{FSH}$-induced preantral follicle growth during a 4-d culture period (Fig. 4A). Whereas basal follicular vol- ume in the CTL MO group was significantly increased by $\mathrm{d} 4(36.8 \pm 3.4 \%)$, a decrease was noted in the GDF-9 MO group $(-19.5 \pm 1.2 \%)$, resulting in a significant difference between the two experimental groups $(P<0.01$; Fig. $4, A$ and $B)$. In the presence of FSH $(10 \mathrm{ng} / \mathrm{ml})$, GDF-9 down-regulation also suppressed follicular growth $[77.1 \pm 8.8 \%$ (CTL MO + $\mathrm{FSH}_{10}$ ) vs. $16.6 \pm 4.7 \%$ (GDF-9 $\mathrm{MO}+\mathrm{FSH}_{10}$ ), $P<$ 0.01 ; Fig. 4A]. The effect of GDF-9 MO appeared to be specific to GDF-9, because the addition of GDF-9 to the culture media prevented the follicular growth arrest caused by GDF-9 MO injection. No significant difference in the change in follicular volume was observed between the CTL MO $(36.8 \pm 3.4 \%)$ and the GDF-9 $\mathrm{MO}+$ GDF-9 $(28.7 \pm 10.1 \%)$ group $(P>0.05$; Fig. $4 \mathrm{~B})$. No significant difference in the follicular volume change was observed between the CTL MO $+\mathrm{FSH}_{10}$ $(77.1 \pm 8.8 \%)$ and the GDF-9 MO + GDF-9 + FSH $_{10}$ $(72.7 \pm 11.5 \%)$ group $(P>0.05)$.

To assess the role of GDF-9 on oocyte growth during the preantral to early antral transition, oocyte diameter was also measured daily. No significant difference was observed in the increase in oocyte volume between the CTL MO- and the GDF-9 MO-injected follicles [at d $4: 27.6 \pm 5.0 \%$ (CTL MO) vs. $32.7 \pm 3.5 \%$ (GDF-9 MO); $P>0.05]$. Addition of FSH $(10 \mathrm{ng} / \mathrm{ml})$ to the culture medium failed to alter oocyte growth in the CTL MO $(30.8 \pm 4.7 \% ; P>0.05)$ or GDF-9 MO $(36.1 \pm$ $6.6 \% ; P>0.05)$ groups.

\section{GDF-9 Protects Granulosa Cells from Ceramide- Induced Apoptosis}

To determine whether GDF-9 is antiapoptotic on granulosa cells during early antral development, granulosa cells from follicles primarily at the early antral [ $24 \mathrm{~h}$ post-equine choriogonadotropin (eCG)] and large antral/preovulatory ( $48 \mathrm{~h}$ post-eCG) stages of development were cultured with different concentrations of GDF-9 $(0,10$, and $100 \mathrm{ng} / \mathrm{ml})$ and ceramide [an inducer of cell cycle arrest and apoptosis (27); $30 \mu \mathrm{M}$, 
A
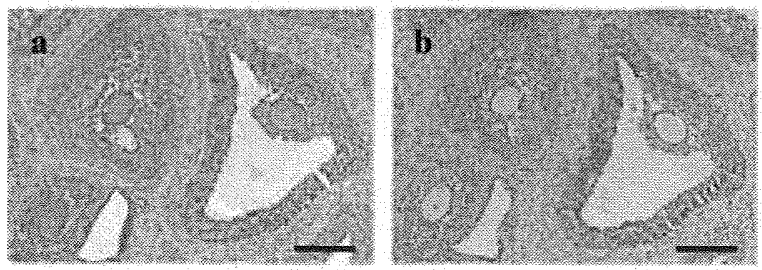

B
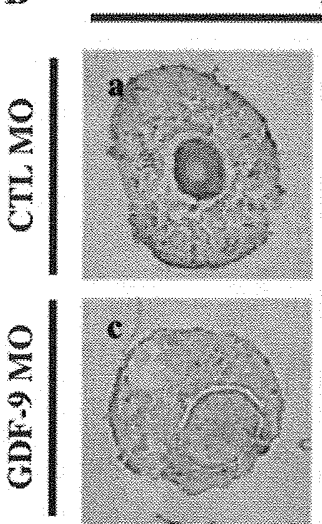

Day 4
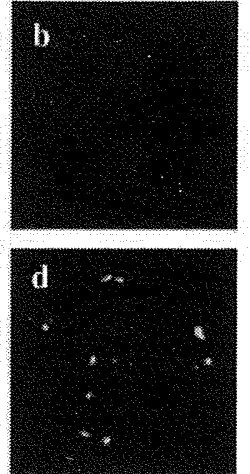

Day 6
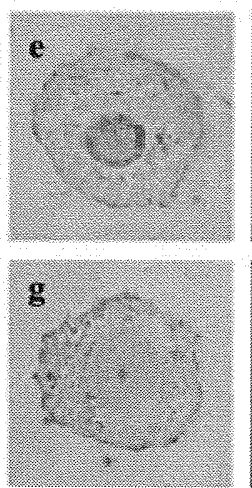

$\mathrm{C}$

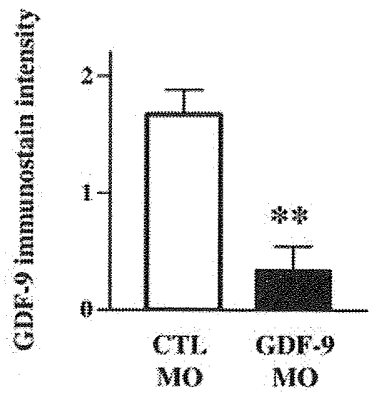

D
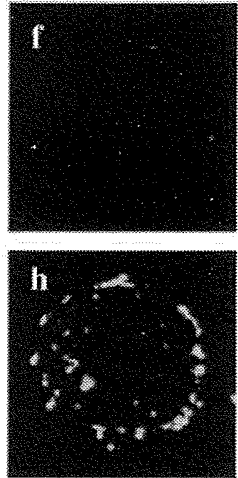

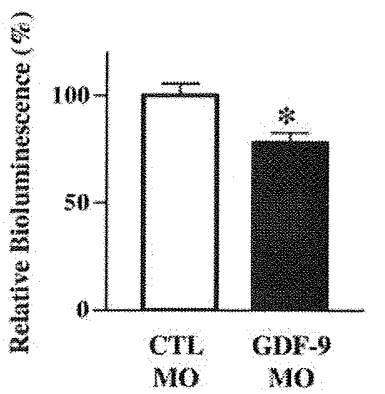

Fig. 3. Effect of Intraoocyte Injection of CTL/GDF-9 MO on Oocyte GDF-9 Expression, Follicular Caspase-3 Activity, and Apoptosis in Vitro

GDF -9 MO (10 $\mu \mathrm{M})$ or CTL MO $(10 \mu \mathrm{M})$ was injected into the oocyte of cultured preantral follicles $(150-180 \mu \mathrm{m}$ in diameter) at $\mathrm{d} 0$. Successful injection was confirmed by visualization of fluorescence in the oocyte. A, GDF-9-positive staining (panel a) and negative control (panel b) in rat ovary. Scale bar, $100 \mu \mathrm{m} . \mathrm{B}, \mathrm{GDF}-9$ expression (immunhistochemistry) and apoptosis (TUNEL) were monitored on $\mathrm{d} 4$ (panels a-d) and d 6 (panels e-h). An image from 10 representative follicles is shown for each treatment group. Note that injection of GDF-9 MO, but not CTL MO, decreased oocyte GDF-9 content and induced follicle cell apoptosis. C, Quantitative result of GDF-9 immunostaining intensity in cultured follicular oocytes ( $n=6$ in each group) injected with CTL MO or GDF-9 MO from three independent experiments. Note that oocytes injected with GDF-9 MO exhibited significantly lower GDF-9 immunostain intensity compared with those with CTL MO $\left.{ }^{* \star}, P<0.01\right)$. D, Caspase-3 activity in CTL MO- and GDF-9 MO-injected follicles on $\mathrm{d} 4$ was assayed. Three follicles from the same treatment group were pooled and served as one sample. Results are represented as means \pm SEM of five independent experiments. Note that GDF-9 MO-injected follicles exhibited decreased bioluminescence, indicating that GDF-9 MO down-regulation in cultured follicles increased caspase-3 activity. ${ }^{*}, P<0.05$ vs. CTL MO-injected follicles.

added $4 \mathrm{~h}$ after GDF-9] and the effect of GDF-9 on ceramide-induced apoptosis was determined by nuclear morphology (Hoechst staining). Treatment with ceramide significantly increased apoptosis in granulosa cells $(P<0.01)$ from both early antral (Fig. 5A) and large antral/preovulatory follicles (Fig. 5B). The ceramide-induced apoptosis was significantly attenuated by the presence of $100 \mathrm{ng} / \mathrm{ml}$ of GDF-9 in cells from early $(P<0.05$; Fig. 5A) but not late $(P>0.05$; Fig. $5 \mathrm{~B})$ stage of follicular development, suggesting that GDF-9 is an antiapoptotic factor for granulosa cells and that its action is dependent on follicular stage.

\section{Activation of PI3K/Akt Pathway Is Involved in the Antiapoptotic Action of GDF-9}

It is well established that activation of the PI3K/Akt pathway protects granulosa cells from proapoptotic signals (28). To determine whether GDF-9 activates PI3K pathways, granulosa cells from early antral folli- cles were incubated with different concentrations of GDF-9 $(0,10$, and $100 \mathrm{ng} / \mathrm{ml})$ for various durations $(0.25,1$, and $4 \mathrm{~h})$, and phospho-Akt (p-Akt) and total Akt content were examined by Western blotting. A very low level of p-Akt was detected in the absence of GDF-9 (Fig. 6A). Preliminary data indicated that FSH $(100 \mathrm{ng} / \mathrm{ml})$ significantly increased $\mathrm{p}$-Akt content within $15 \mathrm{~min}$ in our culture system (data not shown). GDF-9 $(100 \mathrm{ng} / \mathrm{ml})$ significantly increased p-Akt content in granulosa cells after $4 \mathrm{~h}$ treatment $(P<0.01$; Fig. $6 \mathrm{~B})$.

To determine whether the antiapoptotic effect of GDF-9 is mediated via activation of the PI3K/Akt pathway, granulosa cells were pretreated with the PI3K inhibitor LY294002 before the addition of GDF-9 (0 or $100 \mathrm{ng} / \mathrm{ml}$ ) and ceramide ( $30 \mu \mathrm{M})$, and apoptosis was assessed. Pretreatment with LY294002 blocked the protective effect of GDF-9 against ceramide-induced apoptosis $(P<0.05$; Fig. 7A). In addition, the above studies were extended to examine whether downregulation of Akt function by dominant negative Akt 
A

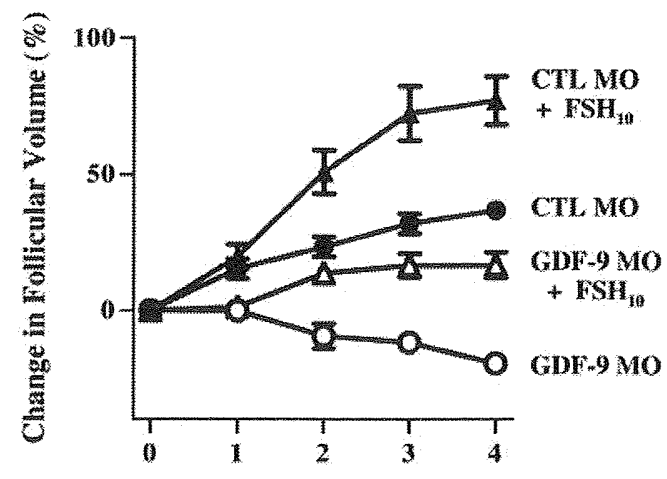

Days after MO Injection

B

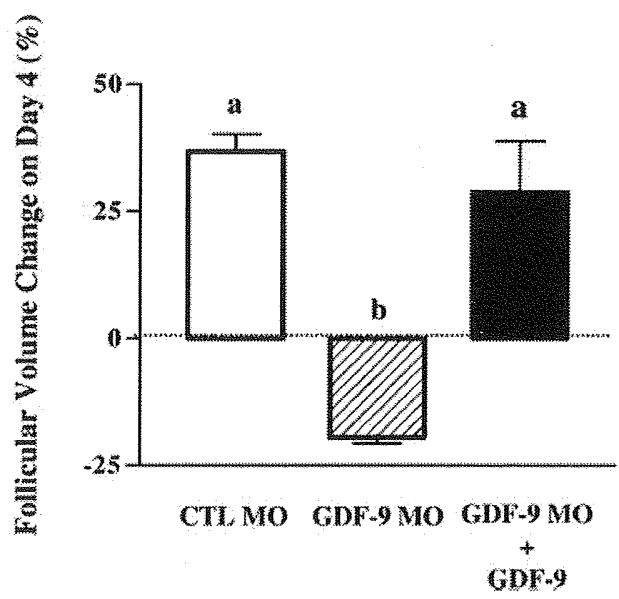

Fig. 4. Intraoocyte Injection of CTL/GDF-9 MO Suppresses Basal and FSH-Induced Preantral Follicle Growth in Vitro

GDF-9 MO $(10 \mu \mathrm{M})$ or CTL MO $(10 \mu \mathrm{M})$ was injected into the oocyte of isolated preantral follicles (150-180 $\mu \mathrm{m}$ in diameter) at $d 0$. At $d 1$, the follicles were treated with or without FSH (10 $\mathrm{ng} / \mathrm{ml}$; panel A) and GDF-9 (100 $\mathrm{ng} / \mathrm{ml}$; panel B) and cultured for another $3 \mathrm{~d}$. Follicular diameter was measured daily, and results were expressed as change in follicular volume. The percentage change of follicular volume on $d$ " $n$ " of culture is defined as the volume difference between $d$ " $n$ " and $\mathrm{d} O$ (the day of injection) expressed as a percentage of the volume at $d 0$. Results represent the means \pm SEM of a total of 16 follicles from four or five independent experiments. A, GDF-9 MO injection suppressed basal and FSH-induced follicle growth during a 4-d culture period. B, Addition of GDF-9 to the culture media prevented the growth arrest on $d$ 4 caused by GDF-9 antisense injection. Bars with different superscripts are significantly different at $P<0.01$.

(dnAkt) expression would attenuate the antiapoptotic action of GDF-9. Granulosa cells from early antral follicles were infected with adenoviral hemagglutinin (HA)-tagged dnAkt or LacZ [as control; multiplicity of infection $(\mathrm{MOI})=40 ; 12 \mathrm{~h}]$. HA content, as determined by Western blotting, was elevated in cells infected with dnAkt, but not with LacZ (Fig. 7C), confirming the infection was successful. Ceramide induced apoptosis in
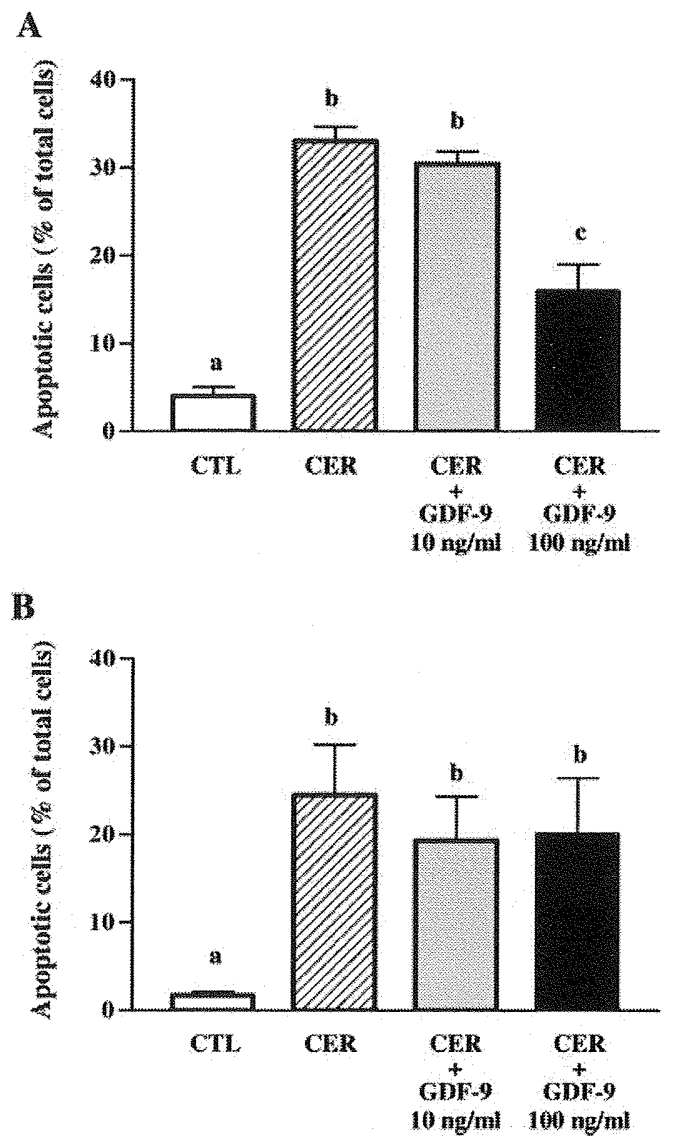

Fig. 5. GDF-9 Attenuates Ceramide-Induced Granulosa Cell Apoptosis

Granulosa cells from follicles mainly at the early antral (24 $\mathrm{h}$ post-eCG; panel A) and large antral/preovulatory ( $48 \mathrm{~h}$ post-eCG; panel B) stages of development were cultured with different concentrations of GDF-9 $(0,10$, and $100 \mathrm{ng} / \mathrm{ml})$ and ceramide (CER: $30 \mu \mathrm{M}$; added $4 \mathrm{~h}$ after GDF-9). CTL, Granulosa cells cultured in the absence of ceramide and GDF-9. The effect of GDF-9 on ceramide-induced apoptosis at $48 \mathrm{~h}$ was determined by nuclear morphology. Results represent means \pm SEM of three or four independent experiments. Note that ceramide-induced apoptosis was attenuated by the presence of GDF-9 $(100 \mathrm{ng} / \mathrm{ml})$ in cells from early (A) but not late (B) stage of follicular development. Within each panel, bars with different superscripts are significantly different at $P<0.05$.

granulosa cells infected with $\operatorname{Lac} Z(P<0.01)$, and this response was attenuated by the presence of GDF- $9(P<$ 0.01 ; Fig. 7B). In granulosa cells infected with dnAkt, the protective effect of GDF-9 against ceramide-induced apoptosis was blocked (Fig. 7B). Taken together, these results indicate that activation of PI3K/Akt pathway is involved in the antiapoptotic action of GDF-9 in granulosa cells of the early antral follicles.

\section{GDF -9 Is Required for the Maintenance of Follicular FSHR mRNA Expression}

To determine whether and what means GDF-9 regulates FSH action during the preantral to early antral 
A

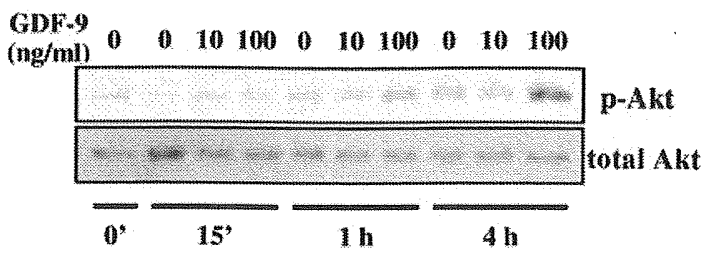

Time after GDF-9

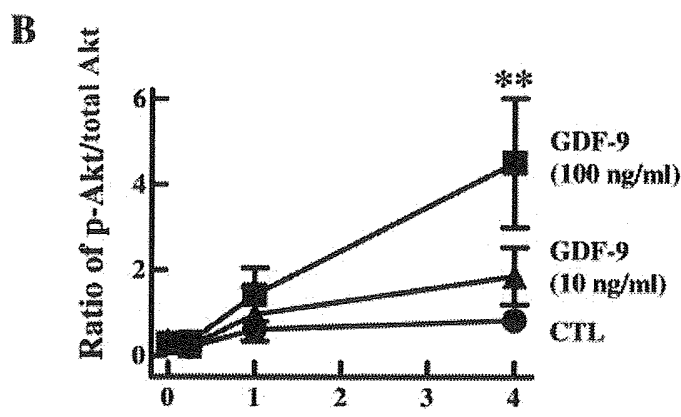

Time after GDF-9 (h)

Fig. 6. GDF-9 Increases p-Akt Content in Granulosa Cells Granulosa cells from early antral follicles were incubated with different concentrations of GDF-9 $(0,10$, and $100 \mathrm{ng} / \mathrm{ml})$ for various durations $(0.25,1$, and $4 \mathrm{~h})$. CTL, Granulosa cells cultured in the absence of GDF-9. p-Akt and total Akt content were examined by Western blotting. Representative images (A) and densitometric data of p-Akt contents (B), expressed as ratio of p-Akt to total Akt, are shown. Results are represented as means \pm SEM of three independent experiments. Note that GDF-9 $(100 \mathrm{ng} / \mathrm{ml})$ increased p-Akt content in granulosa cells after $4 \mathrm{~h}$ treatment. ${ }^{\star \star}, P<0.01$ vs. control (no GDF-9).

transition, real-time quantitative PCR analysis of FSHR was performed on total RNAs from the MO-injected follicles. Whereas treatment with GDF-9 did not alter FSHR mRNA levels in the follicles injected with CTLMO, GDF-9 MO markedly decreased this response (85\%, $P<0.01$; Fig. 8A). The down-regulation of FSHR transcript by GDF-9 MO was prevented by exogenous GDF-9 $(P<0.01$; GDF-9 MO + GDF-9 vs. GDF-9 MO + CTL). FSHR mRNA abundance in GDF-9 $\mathrm{MO}+\mathrm{GDF}-9$ was not different from those in CTL MO + CTL or CTL MO + GDF-9 $(P>0.05$; Fig. 8B). FSH $(10 \mathrm{ng} / \mathrm{ml}$ ) decreased FSHR mRNA levels in the CTL $\mathrm{MO}$-injected follicles after $4 \mathrm{~d}$ culture irrespective of the presence of GDF-9, but had no effect on FSHR mRNA abundance after its down-regulation by GDF-9 MO $(P<0.05$; Fig. 8A).

\section{DISCUSSION}

In the present study, we have demonstrated that the oocyte-derived factor GDF-9 controls the destiny of the ovarian follicle (growth vs. atresia) during follicular
A

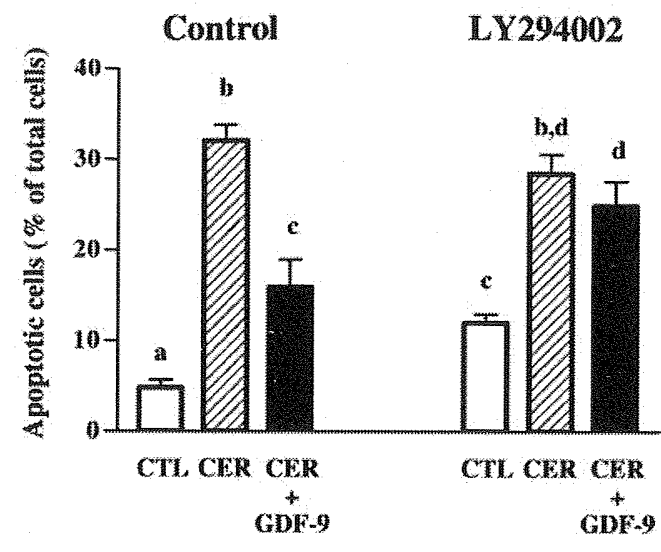

B

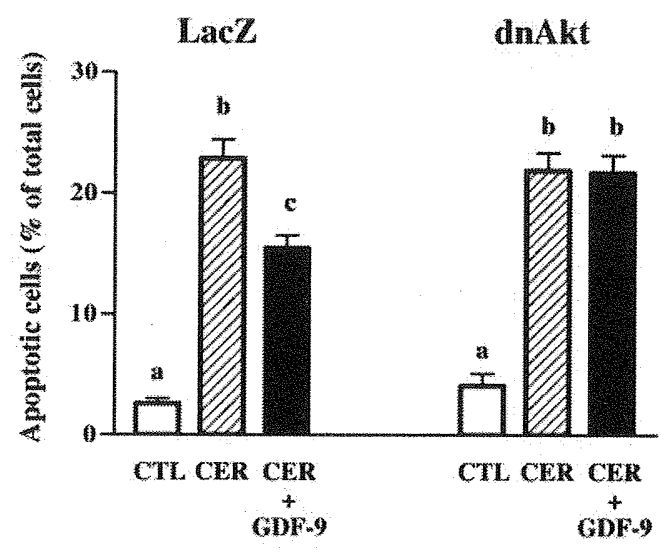

C

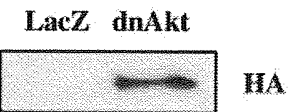

Fig. 7. Effects of the PI3K Inhibitors LY294002 and dnAkt Adenoviral Expression on GDF-9-Mediated Protection from Ceramide-Induced Apoptosis in Granulosa Cells

A, Granulosa cells from early antral follicles were pretreated with the PI3K inhibitor LY294002 ( $t=-0.5 \mathrm{~h}$ ) before the addition of GDF-9 (0 or $100 \mathrm{ng} / \mathrm{ml}, \mathrm{t}=0 \mathrm{~h})$ and ceramide (CER: $30 \mu \mathrm{M}, \mathrm{t}=4 \mathrm{~h}$ ). B, Granulosa cells were infected with adenoviral HA-tagged dnAkt or LacZ (as control; $\mathrm{MOI}=40$; $12 \mathrm{~h}$ ), and then treated with GDF-9 (0 or $100 \mathrm{ng} / \mathrm{ml} ; \mathrm{t}=0 \mathrm{~h}$ ) and ceramide $(30 \mu \mathrm{M} ; \mathrm{t}=4 \mathrm{~h})$. C, To assess infection efficiency, HA in adenovirus-infected cells was assayed at $24 \mathrm{~h}$ by Western blotting, using an anti-HA antibody. CTL, Granulosa cells cultured in the absence of ceramide and GDF-9. Apoptosis was assessed by nuclear morphology at $48 \mathrm{~h}$. Results are represented as means \pm SEM of three independent experiments. Note that the PI3K inhibitor (A) and dnAkt (B) prevented the protective effect of GDF-9 against ceramide-induced apoptosis. Within each panel, bars with different superscripts are significantly different at $P<0.05$.

development from the preantral to early antral stage by regulating granulosa cell apoptosis. We have shown that intraoocyte injection of GDF-9 MO antisense sup- 
A

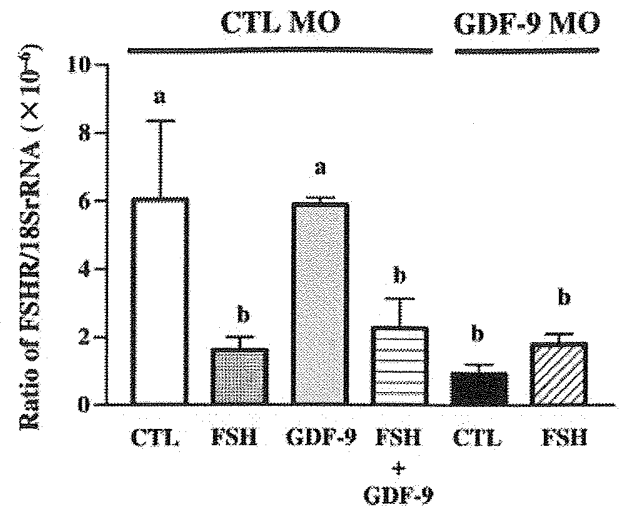

B

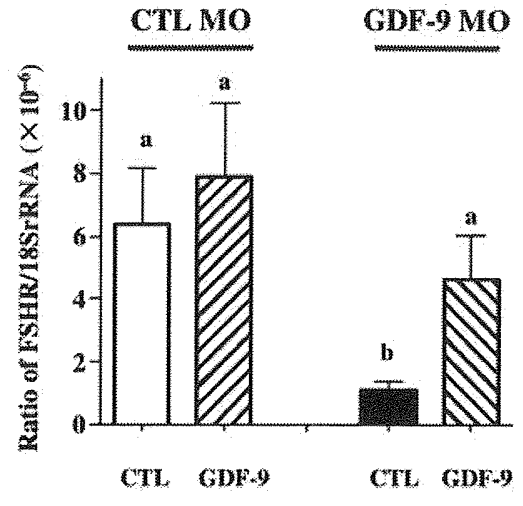

Fig. 8. Effect of Intraoocyte Injection of CTLGDF-9 MO on FSHR Expression in Vitro

GDF-9 MO $(10 \mu \mathrm{M})$ or CTL MO $(10 \mu \mathrm{M})$ was injected into the oocyte of cultured preantral follicles $(150-180 \mu \mathrm{m}$ in diameter). The follicles were cultured for $4 \mathrm{~d}$ with or without FSH $(10 \mathrm{ng} / \mathrm{ml})$ and GDF-9 $(100 \mathrm{ng} / \mathrm{ml})$, and real-time quantitative PCR analysis of FSHR was performed. CTL, Preantral follicles cultured in the absence of GDF-9 and FSH. Total RNAs from three follicles (pooled from the same treatment group) were extracted, and the cDNAs were amplified as one sample. Results are represented as means \pm SEM of three or four (A) or four to seven (B) independent experiments. Note that follicular FSHR mRNA abundance in GDF-9 MO was markedly lower than those in CTL MO and GDF-9 MO + GDF-9. Bars with different superscripts are significantly different at $P<0.05$.

pressed basal and $\mathrm{FSH}$-induced preantral follicle growth in vitro, whereas GDF-9 enhanced basal and $\mathrm{FSH}(10 \mathrm{ng} / \mathrm{ml})$-induced follicular development. GDF-9 $\mathrm{MO}$ activated caspase- 3 and induced apoptosis in cultured preantral follicles, a response attenuated by exogenous GDF-9. GDF-9 protected granulosa cells of early antral follicles from ceramide-induced apoptosis via activation of PI3K/Akt signaling pathway. These results suggest that GDF-9 promotes follicular survival and growth during the preantral to early antral transition by suppressing granulosa cell apoptosis and follicular atresia.

The process of follicular atresia represents a selection system that ensures the release of only healthy and viable oocytes during ovulation $(8,9)$. Although intraovarian regulation, together with the action of $\mathrm{FSH}$, is important for follicular selection, the ovarian factor(s) responsible and precisely when in the developmental process is follicle destiny (growth/ovulation or atresia) determined are not clear. The destiny of the follicle is dependent on a delicate balance in the expression and actions of factors promoting follicle cell proliferation, differentiation, and apoptosis $(8,29)$. The transition of the developing follicle from the preantral to early antral stage is primarily controlled by intraovarian regulators (e.g. GDF-9), but is also responsive to FSH (1). However, continual growth beyond the early antral stage is gonadotropin dependent. The latter contention is supported by the observation that antral follicles cultured in the absence of FSH exhibited abundant apoptosis and follicular growth arrest, a response that could be attenuated by FSH supplementation (30). In addition, as shown in the present study, preantral follicles continued to grow and exhibited minimal apoptosis in the absence of FSH but not of GDF-9 (GDF-9 MO groups), suggesting that this oocyte-derived factor plays a more significant role in promoting cell survival and follicular growth during this early stage of development. In addition, GDF-9 protected granulosa cells from preantral, but not antral, follicles against ceramide-induced apoptosis, suggesting that GDF-9 is necessary for granulosa cell survival during the preantral to early antral transition but is insufficient for antral follicle development, which is dependent on FSH support. Although BMP-15 (GDF-9B), another oocyte-specific member of the TGF- $\beta$ superfamily, is also an important regulator of ovarian function $(19,31,32)$, whether its action in granulosa cells is antiapoptotic and important in protecting the preantral follicles from undergoing atresia remains unknown. Our observation that exogenous GDF-9 is capable of protecting the follicles from GDF-9 MO-induced growth arrest suggests that the antisense was specific to GDF-9.

GDF-9 signals through a complex of type I (activinlike receptor kinase-5) and type II (BMP receptor type II) membrane serine/threonine kinase receptors (33, 34), resulting in the phosphorylation and activation of Sma- and Mad-related protein (Smad)2 and Smad3 in granulosa cells $(33,35,36)$. Smad3 knockout mice exhibited increased atretic follicles and impaired follicle growth (37). Our present finding that intraoocyte injection of GDF-9 MO induced follicle cell apoptosis and suppressed follicular growth is consistent with the above findings but is in contrast with the report that GDF-9-deficient ovaries did not show increased apoptosis (38). The reason for the latter response is unclear although this may be a consequence of growth arrest at the primary stage, which prevented further development to the early antral stage, when apoptosis is most common. 
Gonadotropins and a number of growth factors are known to activate the PI3K/Akt pathway and prevent apoptosis in granulosa cells and cultured follicles $(28$, 30 , 39). PI3K converts phosphatidylinositol-4,5-biphosphate to phosphatidylinositol-3,4,5-triphosphate, leading to activation of downstream kinases including Akt, which in turn phosphorylates Bad, forkhead in rhabdomyosarcome, Fas-associated death domainlike IL-1 $\beta$-converting enzyme-like inhibitory protein, and $X$-linked inhibitor of apoptosis protein (40). Activation of the PI3K/Akt pathway promotes cell survival and proliferation $(10,40-42)$. In the ovary, gonadotropins increase granulosa cell $p$-Akt and $X$-linked inhibitor of apoptosis protein content and suppress apoptosis in vivo and in vitro, whereas withdrawal of gonadotropin support decreases Akt phosphorylation and induces cell apoptosis $(30,39)$. In the present study, GDF-9 activated the PI3K/Akt pathway in granulosa cells of early antral follicles, as evidenced by increased p-Akt content. In addition, the PI3K inhibitor LY294002 and a dominant negative form of Akt prevented the protective effect of GDF-9 against apoptosis induced by ceramide, an intracellular intermediate that directs cell cycle arrest and apoptosis in granulosa cells and ovarian follicles in vitro $(28,43,44)$ and directly antagonizes the PI3K/Akt cell survival pathway $(27,45,46)$. These findings suggest that activation of Akt is necessary for maintenance of granulosa cell survival by GDF-9 and are consistent with the report that Akt overexpression can block ceramide generation and protect cells from ceramide-induced apoptosis in neuron cells (47). The effects of GDF-9 on the PI3K/Akt pathway may be indirect, because p-Akt content was increased only after $4 \mathrm{~h}$ of incubation, whereas FSH can significantly increase p-Akt content within $15 \mathrm{~min}$ in our culture system. A similar phenomenon has been reported by Eppig and colleagues (48), whereby GDF-9 activates MAPK in mouse cumulus cells after $4 \mathrm{~h}$ incubation. Although the precise mechanism for the activation of this pathway by GDF-9 is not known, it is possible that the growth factor-induced p-Akt up-regulation may involve Smad3-mediated down-regulation of phosphatase and tensin homolog (a tumor suppressor that negatively regulates phosphoinositide phosphorylation). In this context, it has been shown that Smad3 interacts with phosphatase and tensin homolog and that TGF- $\beta$-mediated cellular motility and invasion are up-regulated by the loss of this phosphatase (49). Whether this indeed is the case in the cumulus/granulosa cells awaits further investigation.

It is worth noting that although the cell survival action of GDF-9 is at variance with the reported proapoptotic effects of Smad2/3 activation induced by other members of TGF- $\beta$ family in hepatocytes and trophoblast cells $(50,51)$, the possibility exists that, once activated, Akt may bind and sequester Smad3 in the cytoplasm and thus render it incapable of gene activation (52). Thus, the responsiveness of a particular cell type to pro- or antiapoptotic signal is dependent on the ligand as well as the pathway involved.

Although transgenic mouse models have proven to be valuable in assessing the role of genes of interest in mammalian oogenesis and folliculogenesis (53), examination of the specific functions of these genes at late stages of development can sometime be problematic. In this context, we hereby describe the novel establishment of a follicle culture system that is coupled to an in vitro gene manipulation procedure for the assessment of oocyte-granulosa interaction in the growing follicle. This model would provide a useful approach in assessing the role of specific genes in follicular development and atresia in a tissue-specific and time (stage)-controlled manner.

Previous studies have shown that GDF-9-knockout mice exhibited increased oocyte growth relative to controls (21). Although intraoocyte injection of GDF-9 MO suppressed basal and FSH-induced preantral follicle growth in the present study, it had no effect on oocyte size compared with control, irrespective of the presence of FSH. Although the reason for this apparent difference is not clear, it is of interest to note that the influence of GDF-9 on oocyte growth appeared to be dependent on follicular stage [being more significant in smaller follicles than in larger ones (54)]. It is possible that the lack of effect of GDF-9 MO on oocyte growth could be due to the more advanced stage of development at which our studies were conducted. Nonetheless, our results suggest that GDF-9 is involved in the regulation of follicular development from the preantral to early antral stage, but not in that of oocyte growth. Whether GDF-9 MO injection affects oocyte maturation remains to be elucidated.

Although the transition of preantral to early antral follicle can be stimulated by FSH $(1,5)$, our knowledge on the precise role of $\mathrm{FSH}$ at this period remains incomplete. It has been suggested that gonadotropins are not cell survival factors at early stages of folliculogenesis, because preantral follicles in serum-free cultures undergo apoptosis despite exposure to FSH (55). In the present study, whereas preantral follicles $(<200 \mu \mathrm{m}$ in diameter) exhibited only minimal apoptosis, significant apoptotic cell death was noted in follicles that grew to the early antral stage $(>200 \mu \mathrm{m}$ in diameter) in the presence of FSH $(10 \mathrm{ng} / \mathrm{ml})$. This result is consistent with the fact that the vast preponderance of atretic follicles in vivo is present at this stage of development and that atretic preantral follicles are rarely observed $(1,12)$. Although $10 \mathrm{ng} / \mathrm{ml}$ of FSH was insufficient to suppress apoptosis in cultured follicles at the early antral stage, a higher concentration (100 $\mathrm{ng} / \mathrm{ml}$ ) was antiapoptotic. In contrast, the lower concentration of FSH appeared more effective in promoting preantral follicle development than the higher concentration, and follicles cultured in the presence of high concentrations of the gonadotropin exhibited features of cumulus expansion. These results are consistent with the reports that a high FSH concentration promoted in vitro premature granulosa cell differenti- 
ation in oocyte-granulosa cell complexes from mouse preantral follicles (56) and that a low FSH concentration significantly improved oocyte fertilization rate and blastocyst development (57). Low, but not high, FSH concentrations promoted mouse oocyte growth in vitro (58).

Although BMP-15 is known to inhibit FSH activities by suppressing FSHR mRNA expression in granulosa cells irrespective of the presence of FSH (59), precisely how GDF-9 interacts with FSH remains unclear. It has been demonstrated that GDF-9 inhibits FSH-dependent LH receptor expression, CAMP production, and estradiol and progesterone synthesis (24) but markedly enhanced $\mathrm{FSH}$-induced preantral follicle growth in vitro (22) and granulosa cell inhibin $A$ and $B$ production (35). To determine whether the enhancement of FSH-induced follicular growth by GDF-9 observed by Hayashi et al. (22) and in the present study was mediated via increased FSHR expression, we determined FSHR mRNA abundance in preantral follicles after GDF-9 down-regulation. Injection of GDF-9 MO decreased FSHR mRNA levels in the cultured follicles, suggesting that GDF-9 is required for FSHR mRNA expression in preantral follicles. Although exogenous GDF-9 failed to alter FSHR mRNA levels in CTL MOinjected follicles, this might be due to the presence of sufficient endogenous GDF-9 to maintain maximal FSHR mRNA expression during the period. This notion is consistent with the significant increase in FSHR mRNA levels in GDF-9 MO-injected follicles treated with GDF-9 (Fig. 8B). Moreover, GDF-9 enhanced $\mathrm{FSH}$-induced preantral follicle growth and cotreatment with GDF-9 suppressed the apoptosis in follicles cultured in the presence of FSH. This result suggests that GDF-9 is involved in the regulation of FSHR mRNA expression, although the detailed mechanism is not clear. However, the fact that exogenous GDF-9 did not affect the down-regulation of FSHR mRNA by FSH suggests that the observed effect of the growth factor on preantral follicle growth and atresia may also involve an interaction downstream of the receptor.

It is well established that FSHR mRNA expression is up-regulated by FSH (60). However, in the present study, addition of FSH $(10 \mathrm{ng} / \mathrm{ml})$ decreased FSHR mRNA levels in the CTL MO-injected/cultured follicles. Although the reason(s) for this difference remains to be determined, gonadotropin receptors are known to be desensitized or down-regulated after prolonged stimulation (61) or after challenge with a single high dose of FSH (62). Luteinization is also associated with decreased expression of FSHR mRNA (63-65). Our finding that $10 \mathrm{ng} / \mathrm{ml}$ of $\mathrm{FSH}$ was insufficient to prevent apoptosis in cultured follicles could be due to downregulation of FSHR mRNA and decreased gonadotropin sensitivity.

In summary, we have established a novel combination of in vitro gene manipulation in the oocyte and preantral follicle culture. Using this in vitro model in combination with primary granulosa cell cultures, we have shown that GDF-9 plays an important role in promoting preantral follicular growth by suppressing atresia. GDF-9 is antiapoptotic and suppresses granulosa cell apoptosis through activation of the PI3K/Akt pathway. GDF-9 is required for FSHR expression during follicular development from preantral to early antral stage.

\section{MATERIALS AND METHODS}

\section{Materials}

All culture media and supplements were purchased from Life Technologies Inc. (Burlington, Ontario, Canada). Bovine insulin, human transferrin, ascorbic acid, sodium selenite anhydrous, L-glutamine, agarose (low gelling temperature), eCG, trypsin, trypsin inhibitor, PI3K inhibitor (LY294002), and Hoechst 33258 compound were obtained from Sigma Chemical Co. (St. Louis, MO). Recombinant human FSH was obtained from the National Hormone \& Peptide Program, Harbor-UCLA Medical Center (Torrance, CA). MOs for CTL and GDF-9 were purchased from Gene-Tools, LLC (Philomath, Oregon). ICSI (Intracytoplasmic Sperm Injection) micropippets (no. MIC-35-30) were from Humagen (Charlottesville, VA). Goat antihuman GDF-9 antibody $(\mathrm{C}-18)$ and its blocking peptide, as well as goat ImmunoCruz staining system were from Santa Cruz Biotechnology, Inc. (Santa Cruz, CA). TUNEL enzyme and TUNEL label mix were from Roche Diagnostics (Indianapolis, IN). Cleavalite caspase-3 activity assay kit was from Chemicon International, Inc. (Temecula, CA). C8-ceramide ( $N$-octanoylsphingosine, D-erythro) was from Biomol International LP (Plymouth Meeting, PA). Deoxyribonuclease I and RevertAid Enzyme (H Minus M-MuLV RT) were from Fermentas International, Inc. (Burlington, Ontario, Canada). Rabbit antimouse p-Akt (Ser473) and total Akt antibodies were from Cell Signaling Technology (Oakville, Ontario, Canada). Horseradish peroxidase (HRP)-conjugated antirabbit antibodies were from Bio-Rad Laboratories, Inc. (Mississauga, Ontario, Canada). Adenoviral construct with LacZ cDNA was prepared by the Adenovirus Core Facility, University of Ottawa Neuroscience Research Institute (Ottawa, Ontario, Canada). Enhanced chemiluminescence Western blotting detection reagents were from Amersham Biosciences (Baie d'Urfe, Quebec, Canada). RNeasy Micro kit and QuantiTect SYBR Green PCR kit were purchased from QIAGEN, Inc. (Mississauga, Ontario, Canada). PCR primers for FSHR and 18S rRNA were from Invitrogen Canada, Inc. (Burlington, Ontario, Canada). Random Decamer Primers were from Ambion, Inc. (Austin, TX). Recombinant rat GDF-9, adenoviral dnAkt construct containing HA-tagged, triple-A mutation (K179A, T308A, and S473A; kinase dead) were generously provided by Dr. Aaron J. W. Hsueh (Stanford University School of Medicine, Stanford, CA) and Dr. Kenneth Walsh (Cardiovascular Research, St. Elizabeth's Medical Centre, Boston, MA), respectively.

\section{Preantral Follicle Isolation and Culture}

All the animal work was carried out in accordance with the guidelines of the Canadian Council on Animal Care and approved by the Ottawa Health Research Institute Animal Care Committee. Female Sprague Dawley rats were obtained from Charles River Canada (Montreal, Quebec, Canada) and maintained under standard conditions. Large preantral follicles (diameter, 150-180 $\mu \mathrm{m}$ ) from 14-d-old rats known to exhibit negligible apoptosis (55) were isolated in Leibowitz L-15 medium with $\mathrm{BSA}(0.1 \%$, wt/vol) at $\mathrm{d} 0$, using 28.5 -gauge needles (Becton Dickinson and Co., Franklin Lakes, NJ). Only round follicles with intact basement membrane and theca 
layer were selected for the present studies because follicles lacking basement membrane or theca layer were broken or ruptured at a high rate, after the treatment with FSH/GDF-9 or microinjection. Follicles were cultured individually for $4 \mathrm{~d}$ in a 96-well plate (Sarstedt, Inc., Newton, NC; no. 83.1837.50) in $100 \mu \mathrm{l}$ of $\alpha$-MEM supplemented with HEPES (10 mM), BSA $(0.1 \%$, wt/vol), bovine insulin $(5 \mu \mathrm{g} / \mathrm{ml})$, transferrin $(2 \mu \mathrm{g} / \mathrm{ml})$, ascorbic acid $(25 \mu \mathrm{g} / \mathrm{ml})$, sodium selenite anhydrous (2 $\mathrm{ng} /$ $\mathrm{ml})$, L-glutamine ( $3 \mathrm{~mm})$, sodium pyruvate $(100 \mu \mathrm{g} / \mathrm{ml})$, streptomycin $(100 \mu \mathrm{g} / \mathrm{ml})$, and penicillin $(100 \mathrm{U} / \mathrm{ml})$ with or without $100 \mathrm{ng} / \mathrm{ml}$ of GDF-9 and different concentrations of FSH (10 or $100 \mathrm{ng} / \mathrm{ml}$ ). Preliminary data indicated that $100 \mathrm{ng} / \mathrm{ml}$ of GDF-9 or $5 \mathrm{ng} / \mathrm{ml}$ of FSH are the minimal effective concentrations for inducing a significant increase in preantral follicle growth in our culture system. Follicular diameter was measured daily as the average distance between the outer edges of the basement membrane in two perpendicular planes, and results were expressed as change in follicular volume. The percentage change of follicular volume on $d$ " $n$ " of culture is defined as the volume difference between $d$ " $n$ " and $d 0$ (the day of isolation) expressed as a percentage of the volume at $\mathrm{d} 0$. The culture medium was changed every other day, and the spent media were kept at $-20 \mathrm{C}$ for further analysis. At the end of the 4-d culture period, follicles were fixed in buffered formalin phosphate solution [10\%, wt/vol; $24 \mathrm{~h}$, room temperature (RT)], embedded in agarose $(2 \%, w t / v o l)$, stained with Nuclear Fast Red solution (4 h, RT; to facilitate visualization of follicles during sectioning; Sigma-Aldrich, St. Louis, MO), processed, and embedded in paraffin.

\section{Intraoocyte Injection of Morpholinos in Cultured Preantral Follicles}

Expression of MOs is effective in suppressing translation of target genes in zebrafish (66) and Xenopus (67) embryos. To assess the role of GDF-9 on follicular development and atresia during the preantral to early antral transition, GDF-9 content in the cultured follicles was manipulated by intraoocyte microinjection of GDF-9 MO. The GDF-9 MO sequence was designed based on its rat cDNA sequence (5'-ACAGGAATCTGCTGGGAAATGCCAT-3'; not homologous with BMP-15/GDF-9B cDNA), whereas the control MO (CTL MO) sequence $\left(5^{\prime}\right.$-CCTCTTACCTCAGTTACAATTATA-3') was designed by Gene-Tools. Large preantral follicles were isolated from 14-d-old rats and cultured individually in a 96-well plate without GDF-9 or FSH. After 16-24 h, only the follicles (diameter, 150-180 $\mu \mathrm{m}$ ) with intact basement membrane and thecal layer were selected for the microinjection. CTL MO or GDF-9 MO $(10 \mu \mathrm{M})$ was injected into the oocyte of the preantral follicles at $\mathrm{d} 0$. The volume of $\mathrm{MO}$ injected $(3 \mathrm{pl})$ was less than $5 \%(\mathrm{vol} / \mathrm{vol})$ of the oocyte volume. Successful injection was confirmed by visualization of fluorescence (Lissamine tag). At d 1 (i.e. $24 \mathrm{~h}$ after intraoocyte injection), the oocyte morphology was evaluated microscopically, and only follicles with morphologically intact oocytes were cultured with or without GDF-9 $(100 \mathrm{ng} / \mathrm{ml})$ and FSH $(10 \mathrm{ng} / \mathrm{ml})$ for another $3 \mathrm{~d}$. Follicular diameter was measured daily, and the culture medium was changed every other day. The percentage change of follicular volume on $d$ " $n$ " of culture is defined as the volume difference between $d$ " $n$ " and $d 0$ (the day of microinjection) expressed as a percentage of the volume at $d$ 0 . At the end of the culture period, follicles were collected for further analyses.

\section{TUNEL and GDF-9 Immunohistochemistry}

To detect cell death in follicles on $\mathrm{d} 4$ and 6 of culture, TUNEL was performed as described previously (30). Briefly, paraffinembedded follicle sections (thickness, $5 \mu \mathrm{m}$ ) were mounted on positively charged slides (VWR International Ltd., Mississauga, Ontario, Canada; no. 48311-703), deparaffinized, hydrated, and immersed in PBS with $3 \%(\mathrm{vol} / \mathrm{vol}) \mathrm{H}_{2} \mathrm{O}_{2}(10 \mathrm{~min}$,
RT; to inhibit endogenous peroxidase activity). The sections were then incubated in $50 \mu \mathrm{l}$ of the TUNEL mixture $(47.5 \mu \mathrm{l}$ of TUNEL label containing fluorescein isothiocyanate-conjugated dUTP and $2.5 \mu$ l of TUNEL enzyme) in a humidified chamber (60 $\mathrm{min}, 37 \mathrm{C}$ ). The sections were photographed on a Leica microscope (Leica Lasertechnik GmBH, Heidelberg, Germany) equipped with epifluorescent optics. As a negative control, sections were incubated with $50 \mu \mathrm{l}$ of TUNEL-label solution containing no TUNEL enzyme.

After TUNEL observation, the same slides were immediately used for immunolocalization of GDF-9 in the cultured follicles. Antigen retrieval by microwave treatment was performed in $10 \mathrm{~mm}$ sodium citrate buffer ( $\mathrm{pH} \mathrm{6.0;10} \mathrm{min).}$ Sections were sequentially incubated in $\mathrm{H}_{2} \mathrm{O}_{2}(3 \% ; 10 \mathrm{~min}$, $\mathrm{RT}$ ), blocking serum (30 min, RT), goat antihuman GDF-9 antibody (1:200 of dilution; overnight, $4 \mathrm{C}$ ), biotinylated secondary antibody (30 min, RT), and HRP-streptavidin (30 min, RT) in a humidified chamber. Final visualization of antigen was achieved with diaminobenzidine/ $\mathrm{H}_{2} \mathrm{O}_{2}$ solution for $8 \mathrm{~min}$. The sections were then mounted for photography. Primary antibody preabsorbed with its blocking peptide (10x; overnight, $4 \mathrm{C}$ ) was used for negative control. The intensity of GDF-9 immunostain in six oocytes for each group at d 4 of culture was semiquantified using a relative scale: 0,1 , and 2 for no (Fig. 3B, panel g), weak (Fig. 3B, panel e), and strong (Fig. 3B, panel a) staining, respectively.

\section{Activated Caspase-3 Assay for Cultured Follicles}

To provide a quantitative assessment of apoptosis in MOinjected cultured follicles, caspase- 3 activity was examined by the CleavaLite caspase- 3 activity assay kit. Three follicles on d 4 from the same treatment group were pooled for analysis. In accordance with the manufacturer's instructions, caspase- 3 activity in follicular lysates was determined by measuring the amount of specific bioluminescent substrate, which upon cleavage by caspase-3, exhibits decreased bioluminescence. Fold-increase in caspase-3 activity was calculated as relative bioluminescence by comparing the results from the GDF-9 MO-injected follicles with the level of the CTL $\mathrm{MO}$-injected follicles.

\section{Granulosa Cell Isolation and Culture}

Immature female Sprague Dawley rats (21-22 d old) were injected Sc with eCG (10 IU). Ovaries were collected in Leibowitz L-15 medium with BSA $(0.1 \%$, wt/vol $) 24 \mathrm{~h}$ thereafter, and granulosa cells from mainly early antral follicles were harvested by follicle puncture. Oocytes were removed from the cell preparations by filtering the cell suspensions through a nylon cell strainer $(40 \mu \mathrm{m}$; Becton Dickinson and Co., no. 352340 ). At d $0,5 \times 10^{5}$ viable granulosa cells (determined by Trypan blue dye-exclusion test), were cultured for $24 \mathrm{~h}$ in a 12-well plate with $1 \mathrm{ml}$ of RPMI 1640 medium [supplemented with HEPES $(10 \mathrm{~mm})$, streptomycin $(100 \mu \mathrm{g} / \mathrm{ml})$, penicillin $(100$ $\mathrm{U} / \mathrm{ml})$, and fungizone $(0.625 \mu \mathrm{g} / \mathrm{ml})]$ containing fetal bovine serum $(10 \%$, wt/vol). The media were then replaced with serum-free RPMI 1640 supplemented as above, and cells were treated with different concentrations of GDF- $9(0,10$, or $100 \mathrm{ng} / \mathrm{ml})$. Four hours thereafter, C8-ceramide ( $30 \mu \mathrm{M}$; a cell-permeable, short-chain ceramide analog) or dimethylsulfoxide (vehicle control), were added. In some experiments, cells were pretreated with the PI3K inhibitor LY294002 (10 $\mu \mathrm{M} ; 0.5 \mathrm{~h}$ before GDF-9). Floating cells and cells attached to the growth surface (collected by trypsin treatment) were pooled $2 \mathrm{~d}$ thereafter and assessed for apoptosis.

To obtain a granulosa cell preparation with minimal nonviable cells for Western blot analysis, granulosa cells were then treated sequentially in serum-free medium containing trypsin $(20 \mu \mathrm{g} / \mathrm{ml} ; 1 \mathrm{~min})$, trypsin inhibitor $(300 \mu \mathrm{g} / \mathrm{ml} ; 6 \mathrm{~min})$, and deoxyribonuclease $\mathrm{I}(100 \mu \mathrm{g} / \mathrm{ml} ; 6 \mathrm{~min})$ at $37 \mathrm{C}$, as previously described (68). After two rinses, $4-5 \times 10^{5}$ viable 
cells were incubated in $1 \mathrm{ml}$ of serum-free RPMl $1640 \mathrm{me}$ dium (supplemented as described above) with different concentrations of GDF-9 $(0-100 \mathrm{ng} / \mathrm{ml})$ for various durations $(0.25,1$, and $4 \mathrm{~h})$.

\section{Adenoviral Infection of Granulosa Cells}

Viable granulosa cells $\left(5 \times 10^{5}\right)$ were cultured overnight in a 12-well plate with $1 \mathrm{ml}$ of RPMI 1640 medium (supplemented as above) containing fetal bovine serum (10\%). They were then infected $(\mathrm{MOI}=40$ ) with adenoviral dnAkt or LacZ (as control) in RPMI 1640 containing $2 \%$ fetal bovine serum. Media were replaced $12 \mathrm{~h}$ thereafter with serum-free RPMI (supplemented as above) with or without ceramide and/or GDF-9. Cells were collected $48 \mathrm{~h}$ later for subsequent analyses. At $\mathrm{MOI}=10$, the adenoviral LacZ infection efficiency over $48 \mathrm{~h}$ (as determined by $\mathrm{X}$-gal assay) was more than $90 \%$.

\section{Analysis of Granulosa Cell Apoptosis}

At the end of the culture period, floating cells and cells attached to the growth surface were pooled, as described earlier, and stained with Hoechst staining buffer $(62.5 \mu \mathrm{g} / \mathrm{ml}$, in $10 \%$ formalin; overnight, $4 \mathrm{C}$ ). Apoptotic cells were identified based on their typical apoptotic nuclear morphology (e.g. nuclear fragmentation, presence of apoptotic bodies) under fluorescent microscope, as previously reported (30, 69 ). At least 200 cells in a randomly selected area in each treatment group were assessed. To avoid experimental bias, the "counter" was not aware of the treatment.

\section{Western Blot Analysis for Phospho-Akt}

Combined floating and attached cells collected at the end of the culture period were centrifuged $(10 \mathrm{~min}, 250 \times \mathrm{g})$, and the resulting pellets were suspended in a ice-cold lysis buffer [HEPES (50 mm), $\mathrm{NaCl}(150 \mathrm{~mm})$, EGTA (1 mM), sodium pyrophosphatate (10 mM), $\mathrm{MgCl}_{2}(1.5 \mathrm{~mm}), \mathrm{NaF}(100 \mathrm{~mm})$, glycerol $(10 \%)$, and Triton $\mathrm{X}-100(1 \%)$ in PBS] containing a protease inhibitor cocktail [PMSF $(1 \mathrm{~mm})$, aprotinin $(10 \mu \mathrm{g} / \mathrm{ml})$, and sodium orthovanadate $(1 \mathrm{~mm})]$. Cells were sonicated, and lysates were frozen until further analysis. Protein content of cell lysates was determined with the Bio-Rad DC Protein Assay Reagent. Protein lysates $(50 \mu \mathrm{g})$ were separated by $12 \%$ SDS-PAGE and electrotransferred to nitrocellulose membranes. Nonspecific binding to the membranes was blocked with dehydrated nonfat milk $(5 \%, 1 \mathrm{~h}, \mathrm{RT})$. Blots were incubated with anti-p-Akt antibody (dilution 1:1000; overnight, $4 \mathrm{C}$ ) and then with HRP-conjugated secondary antibody ( $1 \mathrm{~h}, \mathrm{RT})$. Peroxidase activity was visualized with the enhanced chemiluminescence kit, and membranes were exposed to x-ray film (Kodak Canada, Inc., Toronto, Ontario, Canada). After p-Akt detection, membranes were stripped and then reprobed with anti-Akt antibody (dilution 1:1000) for total Akt. Signals were quantified densitometrically using Scion Image Software (Scion Corp., Frederick, MD), and ratio of p-Akt to total Akt was calculated.

\section{Real-Time PCR Analysis of FSHR Expression}

Total RNAs from three MO-injected follicles (pooled from the same experiment group) were extracted, using RNeasy Micro kit according to manufacturer's instructions. RNAs were reverse transcribed in a final volume of $20 \mu$ l solution containing $1 \times$ First-Strand Buffer $(3 \mathrm{~mm} \mathrm{MgCl} ; 75 \mathrm{~mm} \mathrm{KCl} ; 50 \mathrm{~mm}$ Tris- $\mathrm{HCl}, \mathrm{pH} 8.3), 500 \mu \mathrm{M}$ each deoxynucleotide triphosphate, $10 \mathrm{~mm}$ dithiothreitol, $100 \mathrm{U}$ of RevertAid Enzyme, 100 ng Random Decamer Primers, and total RNA. Real-time quantitative PCR analysis for FSHR was performed on the follicular cDNAs, using a LightCycler 2.0 System (Roche Di- agnostic Corp.). The FSHR primers used for amplification were a 5 '-forward primer (5'-CATCACTGTGTCCAAGGCCA$\left.3^{\prime}\right)$ and a $3^{\prime}$-reverse primer $\left(5^{\prime}\right.$-TGCGGAAGTTCTTGGTGAAAA-3'), as previously described by Romero et al. (70). FSHR transcript level was normalized on the basis of the level of transcripts for $18 \mathrm{~S}$ rRNA $\left(5^{\prime}\right.$-forward primer; $5^{\prime}$-CGCGGTTCTATTTTGTTGGT-3', $3^{\prime}$-reverse primer; $5^{\prime}$-AGTCGGCATCGTTTATGGTC-3'). Amplification reaction was then performed using the QuantiTect SYBR Green PCR kit. The thermal cycling conditions comprised an initial denaturation step at $95 \mathrm{C}$ for $15 \mathrm{~min}$ and 40 cycles at $95 \mathrm{C}$ for $15 \mathrm{sec}, 58$ $\mathrm{C}$ (FSHR) or $56 \mathrm{C}$ (18S rRNA) for $20 \mathrm{sec}$, and $72 \mathrm{C}$ for $30 \mathrm{sec}$. The level of FSHR mRNA was expressed as a ratio to $18 \mathrm{~S}$ rRNA values.

\section{Statistical Analysis}

Results are presented as means \pm SEM of at least three independent experiments, as detailed in the figure legends. All data were subjected to one- or two-way (repeated-measure) ANOVA, except unpaired $t$ test for caspase-3 activity assay and immunostaining intensity of GDF-9 in oocytes (Prism 3.0 statistical software; GraphPad Software, Inc., San Diego, CA). Differences between experimental groups were determined by the Tukey or Bonferroni post test. Statistical significance was inferred at $P<0.05$.

\section{Acknowledgments}

We thank Dr. Aaron J. W. Hsueh (Stanford University School of Medicine, Stanford, CA) and Dr. Kenneth Walsh (Cardiovascular Research, St. Elizabeth's Medical Centre, Boston, MA) for providing the recombinant rat GDF-9 and the adenoviral construct containing kinase-dead dnAkt, respectively.

Received September 2, 2005. Accepted May 25, 2006.

Address all correspondence and requests for reprints to Benjamin K. Tsang, Ottawa Health Research Institute, The Ottawa Hospital (Civic Campus), 725 Parkdale Avenue, Ottawa, Ontario, Canada K1Y 4E9. E-mail: btsang@ohri.ca.

This work was supported by grants from the Canadian Institutes of Health Research (CIHR) (Grant MOP-10369 to B.K.T.) and the University of Ottawa International Creative Research Initiatives Grant 100146 (to B.K.T.) and was a part of the Program on Oocyte Health (www.ohri.ca/oocyte) funded under the Healthy Gametes and Great Embryos Strategic Initiative of CIHR Institute of Human Development, Child and Youth Health (Grant HGG62293 to B.K.T.). M.O. is a recipient of a fellowship from the Ministry of Education, Culture, Sports, Science, and Technology, Japan. J.Y.J. is a recipient of a fellowship from the Strategic Training Initiatives in the Research in Reproductive Sciences.

M.O., S.O., J.Y.J., J.C., Y.W., F.K. and B.K.T. have no conflict of interest to declare.

\section{REFERENCES}

1. McGee EA, Hsueh AJ 2000 Initial and cyclic recruitment of ovarian follicles. Endocr Rev 21:200-214

2. Cattanach BM, Iddon CA, Charlton HM, Chiappa SA, Fink G 1977 Gonadotrophin-releasing hormone deficiency in a mutant mouse with hypogonadism. Nature 269:338-340

3. Halpin DM, Charlton HM, Faddy MJ 1986 Effects of gonadotrophin deficiency on follicular development in hypogonadal (hpg) mice. J Reprod Fertil 78:119-125 
4. Richards JS 2001 Perspective: the ovarian follicle-a perspective in 2001. Endocrinology 142:2184-2193

5. Fortune JE 2003 The early stages of follicular development: activation of primordial follicles and growth of preantral follicles. Anim Reprod Sci 78:135-163

6. Kumar TR, Wang Y, Lu N, Matzuk MM 1997 Follicle stimulating hormone is required for ovarian follicle maturation but not male fertility. Nat Genet 15:201-204

7. Gougeon A 1996 Regulation of ovarian follicular development in primates: facts and hypotheses. Endocr Rev 17:121-155

8. Johnson AL 2003 Intracellular mechanisms regulating cell survival in ovarian follicles. Anim Reprod Sci 78: 185-201

9. Hussein MR 2005 Apoptosis in the ovary: molecular mechanisms. Hum Reprod Update 11:162-177

10. Hu CL, Cowan RG, Harman RM, Quirk SM 2004 Cell cycle progression and activation of Akt kinase are required for insulin-like growth factor I-mediated suppression of apoptosis in granulosa cells. Mol Endocrinol 18: 326-338

11. Hirshfield AN 1991 Development of follicles in the mammalian ovary. Int Rev Cytol 124:43-101

12. Hirshfield AN 1988 Size-frequency analysis of atresia in cycling rats. Biol Reprod 38:1181-1188

13. Eppig JJ, Wigglesworth K, Pendola FL 2002 The mammalian oocyte orchestrates the rate of ovarian follicular development. Proc Natl Acad Sci USA 99:2890-2894

14. Matzuk MM, Burns KH, Viveiros MM, Eppig JJ 2002 Intercellular communication in the mammalian ovary: oocytes carry the conversation. Science 296:2178-2180

15. Salustri A, Fulop C, Camaioni A, Hascall VC 2004 Oocyte-granulosa cell intereaction. In: Leung PKC, Adashi $E Y$, eds. The ovary. 2nd ed. San Diego: Elsevier Academic Press; 131-143

16. Vanderhyden BC, Caron PJ, Buccione R, Eppig JJ 1990 Developmental pattern of the secretion of cumulus expansion-enabling factor by mouse oocytes and the role of oocytes in promoting granulosa cell differentiation. Dev Biol 140:307-317

17. Vanderhyden BC, Telfer EE, Eppig JJ 1992 Mouse oocytes promote proliferation of granulosa cells from preantral and antral follicles in vitro. Biol Reprod 46: 1196-1204

18. Chang $\mathrm{H}$, Brown $\mathrm{CW}$, Matzuk MM 2002 Genetic analysis of the mammalian transforming growth factor- $\beta$ superfamily. Endocr Rev 23:787-823

19. Shimasaki S, Moore RK, Otsuka F, Erickson GF 2004 The bone morphogenetic protein system in mammalian reproduction. Endocr Rev 25:72-101

20. McGrath SA, Esquela AF, Lee SJ 1995 Oocyte-specific expression of growth/differentiation factor-9. Mol Endocrinol 9:131-136

21. Dong J, Albertini DF, Nishimori K, Kumar TR, Lu N, Matzuk MM 1996 Growth differentiation factor-9 is required during early ovarian folliculogenesis. Nature 383 : 531-535

22. Hayashi M, McGee EA, Min G, Klein C, Rose UM, van Duin M, Hsueh AJ 1999 Recombinant growth differentiation factor-9 (GDF-9) enhances growth and differentiation of cultured early ovarian follicles. Endocrinology 140: 1236-1244

23. Aaltonen J, Laitinen MP, Vuojolainen $K$, Jaatinen $R$, Horelli-Kuitunen N, Seppa L, Louhio H, Tuuri T, Sjoberg J, Butzow R, Hovata O, Dale L, Ritvos O 1999 Human growth differentiation factor 9 (GDF-9) and its novel homolog GDF-9B are expressed in oocytes during early folliculogenesis. J Clin Endocrinol Metab 84:2744-2750

24. Vitt UA, Hayashi M, Klein C, Hsueh AJ 2000 Growth differentiation factor-9 stimulates proliferation but suppresses the follicle-stimulating hormone-induced differentiation of cultured granulosa cells from small antral and preovulatory rat follicles. Biol Reprod 62:370-377
25. Elvin JA, Clark AT, Wang P, Wolfman NM, Matzuk MM 1999 Paracrine actions of growth differentiation factor-9 in the mammalian ovary. Mol Endocrinol 13:1035-1048

26. Hreinsson JG, Scott JE, Rasmussen C, Swahn ML, Hsueh AJ, Hovatta O 2002 Growth differentiation factor-9 promotes the growth, development, and survival of human ovarian follicles in organ culture. J Clin Endcrinol Metab 87:316-321

27. Ruvolo PP 2001 Ceramide regulates cellular homeostasis via diverse stress signaling pathways. Leukemia 15: $1153-1160$

28. Tilly JL, Pru JK, Rueda BR 2004 Apoptosis in ovarian development, function, and failure. In: Leung PKC, Adashi EY, eds. The ovary. 2nd ed. San Diego: Elsevier Academic Press; 321-352

29. Jiang JY, Cheung CK, Wang Y, Tsang BK 2003 Regulation of cell death and cell survival gene expression during ovarian follicular development and atresia. Front Biosci 8:222-237

30. Wang Y, Rippstein PU, Tsang BK 2003 Role and gonadotrophic regulation of $\mathrm{X}$-linked inhibitor of apoptosis protein expression during rat ovarian follicular development in vitro. Biol Reprod 68:610-619

31. Hashimoto O, Moore RK, Shimasaki S 2005 Posttranslational processing of mouse and human BMP-15: potential implication in the determination of ovulation quota. Proc Natl Acad Sci USA 102:5426-5431

32. Erickson GF, Shimasaki S 2003 The spatiotemporal expression pattern of the bone morphogenetic protein family in rat ovary cell types during the estrous cycle. Reprod Biol Endocrinol 1:9

33. Mazerbourg S, Klein C, Roh J, Kaivo-Oja N, Mottershead DG, Korchynskyi O, Ritvos O, Hsueh AJ 2004 Growth differentiation factor-9 signaling is mediated by the type I receptor, activin receptor-like kinase 5. Mol Endocrinol 18:653-665

34. Vitt UA, Mazerbourg S, Klein C, Hsueh AJ 2002 Bone morphogenetic protein receptor type II is a receptor for growth differentiation factor-9. Biol Reprod 67:473-480

35. Roh JS, Bondestam J, Mazerbourg S, Kaivo-Oja N, Groome N, Ritvos O, Hsueh AJ 2003 Growth differentiation factor-9 stimulates inhibin production and activates Smad2 in cultured rat granulosa cells. Endocrinology 144:172-178

36. Kaivo-Oja N, Bondestam J, Kamarainen M, Koskimies J, Vitt $U$, Cranfield $M$, Vuojolainen $K$, Kallio JP, Olkkonen VM, Hayashi M, Moustakas A, Groome NP, ten Dijke P Hsueh AJ, Ritvos O 2003 Growth differentiation factor-9 induces Smad2 activation and inhibin $B$ production in cultured human granulosa-luteal cells. J Clin Endocrinol Metab 88:755-762

37. Tomic D, Miller KP, Kenny HA, Woodruff TK, Hoyer P Flaws JA 2004 Ovarian follicle development requires Smad3. Mol Endocrinol 18:2224-2240

38. Elvin JA, Yan C, Wang P, Nishimori K, Matzuk MM 1999 Molecular characterization of the follicle defects in the growth differentiation factor 9-deficient ovary. Mol Endocrinol 13:1018-1034

39. Asselin E, Wang Y, Tsang BK 2001 X-linked inhibitor of apoptosis protein activates the phosphatidylinositol 3-kinase/Akt pathway in rat granulosa cells during follicular development. Endocrinology 142:2451-2457

40. Franke TF, Hornik CP, Segev L, Shostak GA 2003 Sugimoto C PI3K/Akt and apoptosis: size matters. Oncogene 22:8983-8998

41. Downward J 2004 PI 3-kinase, Akt and cell survival Semin Cell Dev Biol 15:177-182

42. Thompson JE, Thompson CB 2004 Putting the rap on Akt. J Clin Oncol 22:4217-4226

43. Witty JP, Bridgham JT, Johnson AL 1996 Induction of apoptotic cell death in hen granulosa cells by ceramide. Endocrinology 137:5269-5277 
44. Kaipia A, Chun SY, Eisenhauer K, Hsueh AJ 1996 Tumor necrosis factor- $\alpha$ and its second messenger, ceramide, stimulate apoptosis in cultured ovarian follicles. Endocrinology 137:4864-4870

45. Zundel W, Giaccia A 1998 Inhibition of the anti-apoptotic $\mathrm{PI}(3) \mathrm{K} / A k t / B a d$ pathway by stress. Genes Dev 12: 1941-1946

46. Summers SA, Garza LA, Zhou H, Birnbaum MJ 1998 Regulation of insulin-stimulated glucose transporter GLUT4 translocation and Akt kinase activity by ceramide. Mol Cell Biol 18:5457-5464

47. Goswami R, Kilkus J, Dawson SA, Dawson G 1999 Overexpression of Akt (protein kinase B) confers protection against apoptosis and prevents formation of ceramide in response to pro-apoptotic stimuli. $J$ Neurosci Res 57: 884-893

48. Su YQ, Denegre JM, Wigglesworth $K$, Pendola FL O'Brien MJ, Eppig JJ 2003 Oocyte-dependent activation of mitogen-activated protein kinase (ERK1/2) in cumulus cells is required for the maturation of the mouse oocytecumulus cell complex. Dev Biol 263:126-138

49. Hielmeland $A B$, Hjelmeland $M D$, Shi $Q$, Hart JL, Binger DD, Wang XF, Kontos CD, Rich JN 2005 Loss of phosphatase and tensin homologue increases transforming growth factor $\beta$-mediated invasion with enhanced SMAD3 transcriptional activity. Cancer Res 65: 11276-11281

50. Tanaka S, Wands JR 1996 Insulin receptor substrate 1 overexpression in human hepatocellular carcinoma cells prevents transforming growth factor $\beta 1$-induced apoptosis. Gancer Res 56:3391-3394

51. Munir S, Xu G, Wu Y, Yang B, Lala PK, Peng C 2004 Nodal and ALK7 inhibit proliferation and induce apoptosis in human trophoblast cells. $J$ Biol Chem 279: 31277-31286

52. Remy I, Montmarquette A, Michnick SW 2004 PKB/Akt modulates TGF $-\beta$ signaling through a direct interaction with Smad3. Nat Cell Biol 6:358-365

53. Rajkovic A, Matzuk MM 2002 Functional analysis of oocyte-expressed genes using transgenic models. Mol Cell Endocrinol 187:5-9

54. Carabatsos MJ, Elvin J, Matzuk MM, Albertini DF 1998 Characterization of oocyte and follicle development in growth differentiation factor-9-deficient mice. Dev Biol 204:373-384

55. McGee E, Spears N, Minami S, Hsu SY, Chun SY, Billig H, Hsueh AJ 1997 Preantral ovarian follicles in serumfree culture: suppression of apoptosis after activation of the cyclic guanosine $3^{\prime}, 5^{\prime}$-monophosphate pathway and stimulation of growth and differentiation by follicle-stimulating hormone. Endocrinology 138:2417-2424

56. Eppig JJ, O'Brien MJ, Pendola FL, Watanabe S 1998 Factors affecting the developmental competence of mouse oocytes grown in vitro: follicle-stimulating hormone and insulin. Biol Reprod 59:1445-1453
57. O'Brien MJ, Pendola JK, Eppig JJ 2003 A revised protocol for in vitro development of mouse oocytes from primordial follicles dramatically improves their developmental competence. Biol Reprod 68:1682-1686

58. Thomas FH, Ethier JF, Shimasaki S, Vanderhyden BC 2005 Follicle-stimulating hormone regulates oocyte growth by modulation of expression of oocyte and granulosa cell factors. Endocrinology 146:941-949

59. Otsuka F, Yamamoto S, Erickson GF, Shimasaki S 2001 Bone morphogenetic protein-15 inhibits follicle-stimulating hormone (FSH) action by suppressing FSH receptor expression. J Biol Chem 276:11387-11392

60. Findlay JK, Drummond AE 1999 Regulation of the FSH receptor in the ovary. Trends Endocrinol Metab 10: 183-188

61. Amsterdam A, Hanoch T, Dantes A, Tajima K, Strauss JF, Seger R 2002 Mechanisms of gonadotropin desensitization. Mol Cell Endocrinol 187:69-74

62. Themmen AP, Blok LJ, Post M, Baarends WM, Hoogerbrugge JW, Parmentier M, Vassart G, Grootegoed JA 1991 Follitropin receptor down-regulation involves a cAMP-dependent post-transcriptional decrease of receptor mRNA expression. Mol Cell Endocrinol 78:7-13

63. Camp TA, Rahal JO, Mayo KE 1991 Cellular localization and hormonal regulation of follicle-stimulating hormone and luteinizing hormone receptor messenger RNAs in the rat ovary. Mol Endocrinol 5:1405-1417

64. Rajapaksha WR, Robertson L, O'Shaughnessy PJ 1996 Expression of follicle-stimulating hormone-receptor mRNA alternate transcripts in bovine granulosa cells dur ing luteinization in vivo and in vitro. Mol Cell Endocrinol 120:25-30

65. Yaron $\mathrm{Y}$, Schwartz D, Evans MI, Lessing JB, Rotter $\mathrm{V}$ 1998 Alternatively spliced mRNA transcripts encoding the extracellular domain of the FSH receptor gene. Expression in the mouse ovary during the ovulatory cycle. $J$ Reprod Med 43:435-438

66. Nasevicius A, Ekker SC 2000 Effective targeted gene 'knockdown' in zebrafish. Nat Genet 26:216-220

67. Heasman J, Kofron M, Wylie C $2000 \beta$-Catenin signaling activity dissected in the early Xenopus embryo: a novel antisense approach. Dev Biol 222:124-134

68. Pradeep PK, LiX, Peegel H, Menon KM 2002 Dihydrotestosterone inhibits granulosa cell proliferation by decreasing the cyclin D2 mRNA expression and cell cycle arrest at $G_{1}$ phase. Endocrinology 143:2930-2935

69. Hakuno N, Koji T, Yano T, Kobayashi N, Tsutsumi O, Taketani Y, Nakane PK 1996 Fas/APO-1/CD95 system as a mediator of granulosa cell apoptosis in ovarian follicle atresia. Endocrinology 137:1938-1948

70. Romero C, Paredes A, Dissen GA, Ojeda SR 2002 Nerve growth factor induces the expression of functional FSH receptors in newly formed follicles of the rat ovary. Endocrinology 143:1485-1494 